\title{
Influence of Plasma Treatment in Open Air on Mycotoxin Content and Grain Nutriments
}

\author{
Pavel Kříž,,$^{1, *}$ Bartoš Petr, ${ }^{2}$ Havelka Zbyněk, ${ }^{2}$ Kadlec Jaromír, ${ }^{3}$ Olšan Pavel, ${ }^{2}$ \\ Špatenka Petr, ${ }^{4} \&$ Dienstbier Miroslav ${ }^{5}$
}

${ }^{1}$ Faculty of Education, University of South Bohemia in Ceske Budejovice, Czech Republic; ${ }^{2}$ Faculty of Agriculture and Faculty of Education, University of South Bohemia in Ceske Budejovice, Czech Republic; ${ }^{3}$ Faculty of Agriculture, University of South Bohemia in Ceske Budejovice, Czech Republic; ${ }^{4}$ Faculty of Mechanical Engineering, Czech Technical University in Prague, Czech Republic; ${ }^{5}$ Research Institute of Brewing and Malting in Prague, Czech Republic *Address all correspondence to: Pavel Křřž, University of South Bohemia in Ceske Budejovice, Faculty of Education,
Department of Applied Physics and Technology, Jeronymova 10, 37010 Ceske Budejovice, Czech Republic; Tel.: +420
38777 3053; kriz@pf.jcu.cz

\begin{abstract}
Surface treatment by low-temperature plasma has a great potential in a wide range of applications in many industries and research fields, such as material engineering, automobile industry, ecology, medicine, and agriculture. The application of plasma treatments is relatively new and not very common in agriculture. Protecting cereal seeds against some fungal diseases is one of the plasma applications in agriculture. We tested the possibility of decreased mycotoxin concentration by low pressure and atmospheric pressure plasmas. In addition, we investigated the effects of plasma treatment on nutritive values of the seeds because of their usage as domestic animal feed. The influence on seed germination was also studied and are also reported here.
\end{abstract}

KEY WORDS: gliding arc, microwave plasma discharge, seed treatment, deoxynivalenol, nutritive value

\section{INTRODUCTION}

Low-temperature (LT) plasma is currently used for modification of various surfaces in industry applications, mechanical engineering, and the chemical industry, but its uses for various biological and medical applications are also being intensively studied. Application of LT plasma treatment has been described for killing pathogens and their spores ${ }^{1,2}$; sterilization or inactivation of several bacteria strains, ${ }^{3,4}$ yeast, ${ }^{5,6}$ and viruses ${ }^{7}$; inhibition or deactivation of fungi ${ }^{8-10}$; sterilization of surgical tools ${ }^{11}$ and foodstuffs ${ }^{12}$; and destruction of biological toxins. ${ }^{13} \mathrm{~A}$ successful plasma application in practical medicine to treat inflammatory eye and skin diseases and to stimulate regeneration processes has been also described. ${ }^{14}$ In addition to whole tissues, even single cells can be locally treated by LT plasma. ${ }^{15}$

In the agriculture and food processing industries, the first studies were focused on treatment of grain surfaces and fruits. The positive influence of some LT plasma discharge on germination capacity of chosen plants has been confirmed. ${ }^{16-19}$ One investigation showed that fruit surfaces can be disinfected by plasma treatment. ${ }^{20}$ Plasma has been demonstrated to inhibit fungi on the grain or fruit surface or under the surface. ${ }^{10,21,22}$ 
Mycotoxins are poisonous chemicals produced by some kinds of fungi. They can be transferred from contaminated grains to feed materials and food products (e.g., flour, bread, bakery products, and beer), ${ }^{23,24}$ and so they can cause grave illnesses, metabolic problems, and acute mycotoxin infection in humans and animals. The transfer of mycotoxins from grains to food or feed (and secondary to live organisms) is dependent on their solubility, thermal stability, treatment technology used, and other parameters. ${ }^{25}$ The problem of mycotoxin decontamination is very complicated. The common methods for decontamination are the following: different chemical agents or sorbents, radiation illumination, ozonation, thermal treatment, mechanical abrasion of grains, alkalinization, infusion, glycosidification, isomerization processes, and treatment with chlorine dioxide gas. $^{26-28}$

Although mycotoxins are usually very stable chemical substances, successful use of plasma discharge for their decomposition has been reported by several authors. For example, Park et al. ${ }^{29}$ reported degradation of mycotoxins in microwave-induced plasma discharge at atmospheric pressure in argon. Considering the potential applications of these interesting results for decontamination of animal feed (and eventually human food), we carried out similar experiments in air. In contrast to argon, air is more suitable gas for this purpose, both from technological and economic points of view. These experiments were also supplemented by the examination of the changes in nutritive and biological value of seeds, which might be negatively influenced by the applied plasma.

\section{EXPERIMENTAL METHOD AND MATERIAL}

\section{A. Plasma Devices}

Our experiments were performed in two different laboratory setups. The first one is a low pressure plasma reactor that was described in detail elsewhere ${ }^{30}$ and is schematically drawn in Fig. 1. The system consists of vacuum process chamber made from a stainless steel cylinder with an inner diameter of $250 \mathrm{~mm}$, and it is equipped on the upper and lower side with a standard ISO-K 250 flange. Inside the reactor a stainless steel blender with a horizontal propeller stirrer is placed. The stirrer axe is brought out from the reactor through a vacuum feedthrough placed at the bottom of the reactor. A sealing lip prevents penetration of the treated material into the bearing. An electrical engine placed outside the reactor drives the propeller via a vacuum feedthrough and a vertical movable shaft. This construction allows adjustment of the distance between the blender and the plasma source. The stirrer speed is set electronically. Approximately one revolution per second is typically used in most experiments. The working gas flow and the working pressure were controlled with a set of mass flow controllers MKS 1179A (MKS Instruments, Inc., Macedon, NY, USA) and a regulating valve VAT PM-3 (VAT Group AG, Haag, Switzerland), respectively. A microwave power supply, powered with a pulsed microwave power unit MNG 1K-08 (Radan Ltd., Barchov, Czech Republic) was used as a plasma source. Air was used as the carrier gas. Its flow was 100 SCCM, and the pressure in the vacuum chamber was maintained at $100 \mathrm{~Pa}$; the batch of seeds 


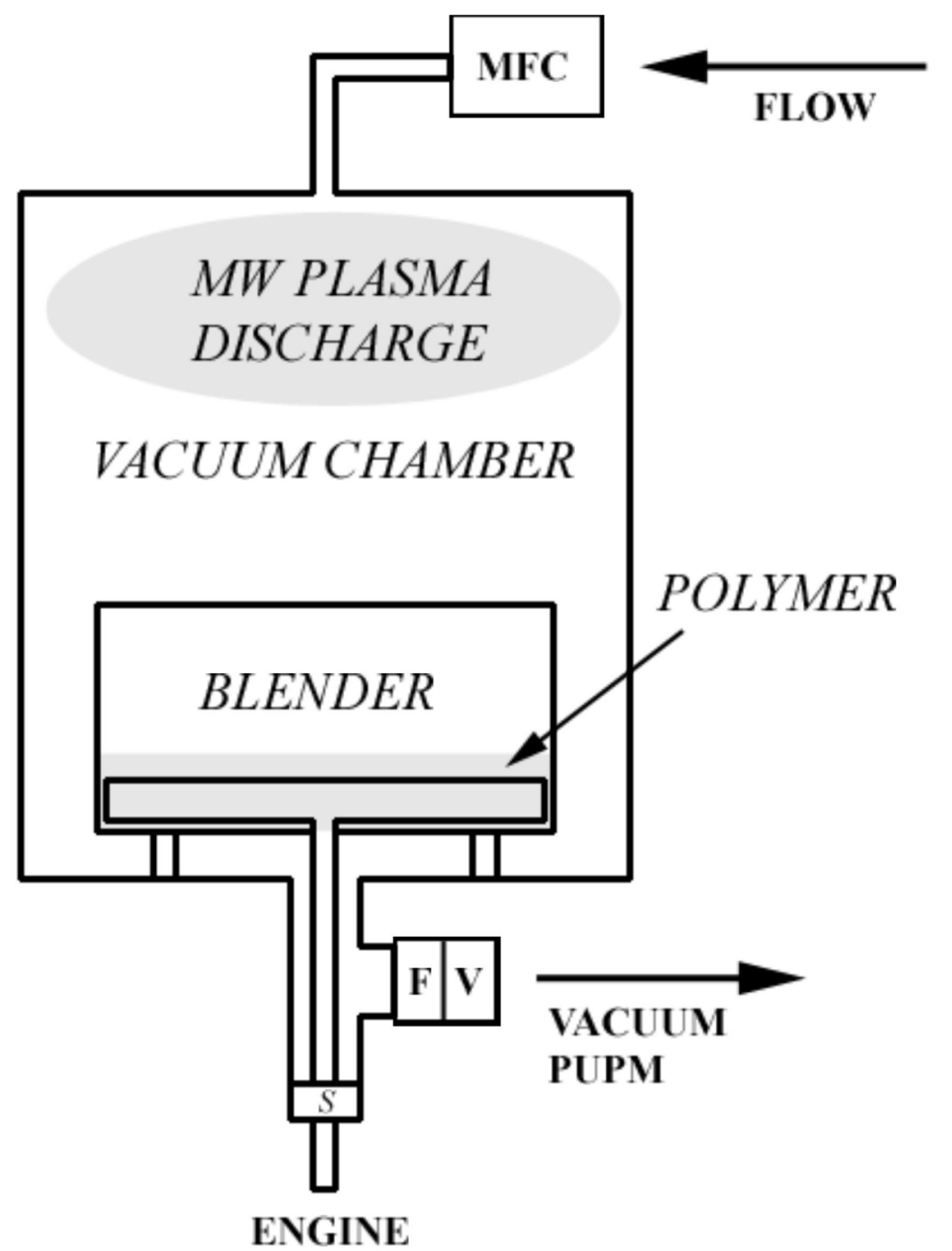

FIG. 1: Schematic of the low pressure plasma reactor

weighed $300 \mathrm{~g}$.

The second plasma system is based on gliding arc discharge. The schematic drawing of the experimental setup is shown in Fig. 2. The plasma source was described in detail by Kriz et al. ${ }^{31}$ The gliding arc discharge is generated by a high voltage power source operated at a frequency of $50 \mathrm{~Hz}$. The discharge burns between two diverging semicircular copper electrodes with a minimal gap of $5 \mathrm{~mm}$. Compressed air with the overpressure maintained at approximately 8 bars is used as the carrier working gas. The air flow rate can vary in the range of 20 to $80 \mathrm{SCFH}$ (standard cubic feet per hour; a gas flow of $1 \mathrm{Nm}^{3} / \mathrm{h}$ correspond to approx. $35 \mathrm{SCFH}$ ). Gas flow was set up with an air flowmeter 

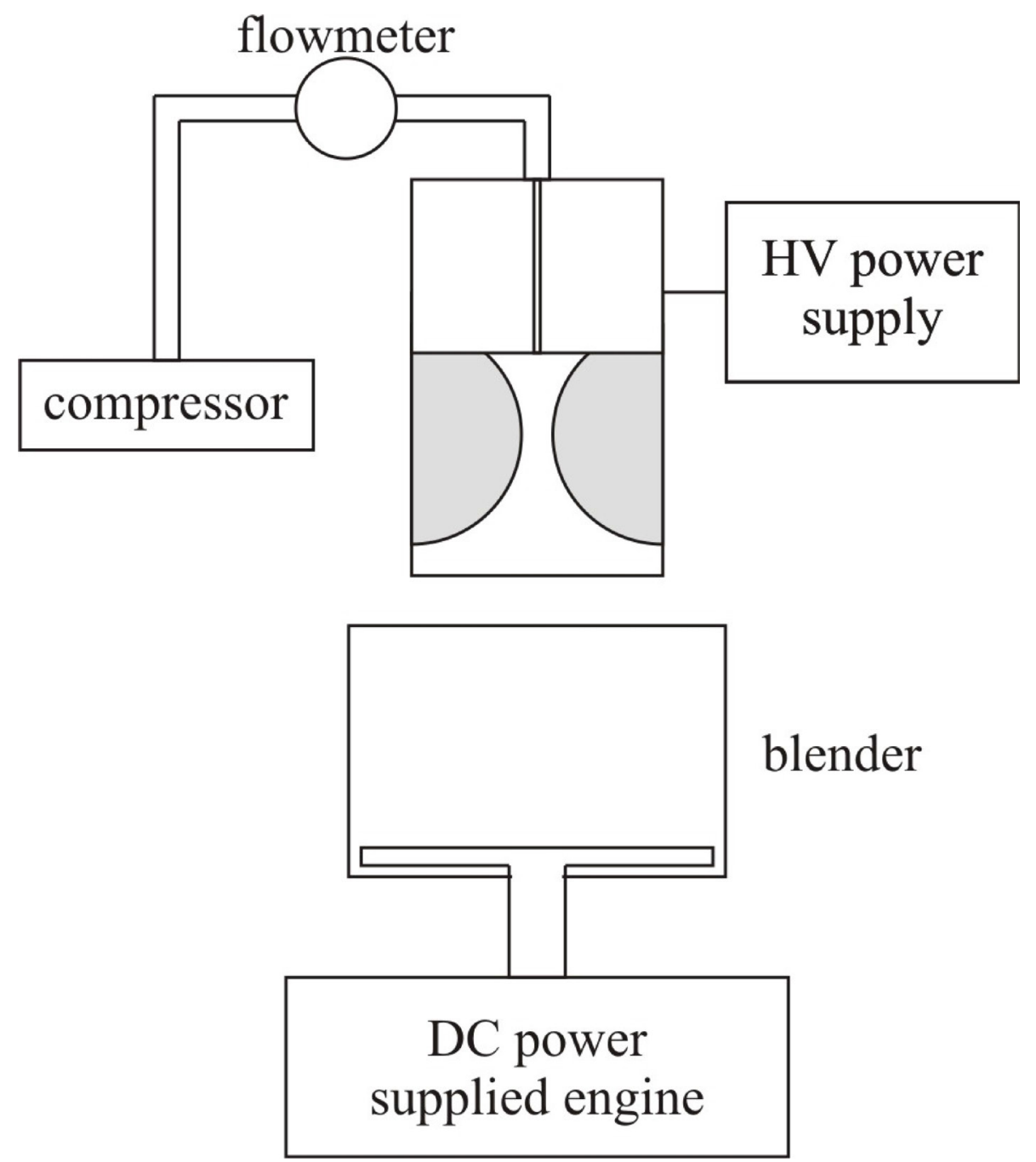

FIG. 2: Experimental setup of plasma system based on gliding arc discharge

Omega FL-2008 (Omega Engineering, Inc., Stamford, CT, USA). The diameter of the working gas inlet is $1 \mathrm{~mm}$. The electrodes are encapsulated in the cover, which exceeds $5 \mathrm{~mm}$ over the electrode tips. The distance between the electrodes cover edge and the seeds was $6 \mathrm{~cm}$; the batch of the seeds weighed $150 \mathrm{~g}$. The seeds were stirred by the propeller to ensure uniform treatment of every seed. One revolution per second is the typical frequency used in the experiments.

\section{B. Mycotoxin Decontamination Analyses}

Malting barley seeds (Hordeum vulgare L.) were used as model crops. The grains were 
naturally contaminated by fungi producing several kinds of mycotoxins, namely deoxynivalenol (DON), deoxynivalenol-3-glucoside (D3G), and trichothecene mycotoxins (T-2). The plasma treatment time varied from 1 to $5 \mathrm{~min}$, depending on the plasma device used. Because of the higher temperature of the process, short durations only up to 4 min were used for atmospheric pressure plasma treatment to prevent unwanted thermal changes in treated grains. After the treatments, mycotoxin concentrations were analyzed.

Mycotoxin concentrations were determined by two methods. In the case of samples treated with the low pressure plasma device, the concentrations of DON and D3G mycotoxins were primarily extracted from milled barley grains by ultrasound into deionized water followed by the cleanup on the DONREP immune-affinity column (R-Biopharm AG, Darmstadt, Germany). Detection and quantification were performed with an HPLC/ MS Finnigan Surveyor/LCQ Advantage Max (Thermo Fisher Scientific, Inc., Waltham, MA, USA).

The parallel method used an enzyme-linked immunosorbent assay (ELISA) for detection of mycotoxins. The apparatus consisted of a microplate ELISA reader OpsysMR (Dynex Technologies, Chantily, VA, USA) equipped with SW Windows Revelation QuickLink software. This method was used for both low pressure and atmospheric pressure plasma treatments, but only for determination of DON and T-2 mycotoxin content.

In this method mycotoxin is extracted from a ground sample using solvent. The extract is then mixed with an enzyme-coupled mycotoxin conjugate and applied to the antibody-coated microtiter wells. Mycotoxin present in the sample extract (or control standards) competes with the enzyme-conjugated mycotoxin for the antibody binding sites. After washing, an enzyme substrate is added and blue color develops. The intensity of the color is inversely proportional to the concentration of mycotoxin in the sample (or standard). A solution is then added to stop the enzyme reaction. The intensity of the solution color in the microtiter wells is measured optically using the ELISA reader with the absorbance filter of $450 \mathrm{~nm}$ and the reference filter of $630 \mathrm{~nm} .{ }^{32}$ The optical densities (OD) of the samples are compared to the ODs of the standards (calibration curve), and the mycotoxin content is calculated.

\section{Nutritive Experiments}

The atmospheric pressure gliding arc system was used in every treatment for nutritive value determination. The experiments were split into two steps. The first one was determination of the basic seed nutritive values, based on a wide range of optional plasma device parameters such as flow rate, process duration, and distance between the plasma source and the seed surface. The original dry matter, ash, fat, crude fiber (CF), and nitrogen-free extract (NFE) were chosen as basic nutriments. The air flow rate parameter that mainly affected the process temperature was varied in the range of 30 to $60 \mathrm{SCFH}$. The treatment time ranged from 1 to 4 minutes. The distance between the edge of the gliding arc jet cover and seed surface was set to 6 and $10 \mathrm{~cm}$, respectively. Triticosecale Wittm. seeds were used as model grains in these experiments. 
In the second experiments, the influence of the treatment on seed nutritive values was performed in more detail. For these tests, wheat grains (Triticum aestivum L.) were used as model crops. Based on the results of the first step, the main optional plasma device parameters were set as follows: air flow, $50 \mathrm{SCFH}$; distance, $6 \mathrm{~cm}$. Only treatment time was set to two different values, 1 and 4 minutes for comparison. Each experiment was repeated several times. Except for the nutriments mentioned earlier, starch, amino acids, crude protein (CP), wet gluten contents, metabolizable energy for poultry (ME), and protein digestibility were determined in this step.

The original dry matter, fat, NFE, starch, and amino acids were determined according to Czech standard. ${ }^{33}$ Grains were dehydrated 6 hours at a temperature of $105^{\circ} \mathrm{C}$ in a laboratory oven Memmert UE 600 (Memmert GmbH, Schwabach, Germany) in order to determine the original dry matter. Fat was extracted by petroleum ether according to the Soxhlet method using an extraction unit Soxtec 2050 (FOSS, Hillerød, Denmark). NFE was calculated as the difference between the dry matter and sum of CP, CF, fat, and ash. Starch content was analyzed with a polarimeter. A sample of the grains was exposed to dilute solution of acid hydrochloric. Optical activity of the filtrate was measured with the polarimeter after protein elimination by two Carrez reagents. The filtrate was analyzed in a 200-mm polarizing tube. Starch was calculated according to the angle of rotation. Amino acids were analyzed after acid hydrolysis in an amino acid analyser (AAA 400, INGOS, Prague) by the method of ion exchange chromatography.

Protein content was determined by the Barnstein method followed by the Kjeldahl method. Subsequently, CP was analysed by the Kjeldahl method, using the protein conversion factor of 6.25 and an automatic distillation unit UDK 132 (Velp Scientifica, Usmate, Italy). ${ }^{34,35} \mathrm{CF}$ was analyzed by acid-alkaline method according to HennebergStohmann with an apparatus Fibertec 2010 (FOSS, Hillerød, Denmark). ${ }^{36}$ To determine ash content the samples were burned in a laboratory furnace 003 LP (Svoboda, Světice u Říčan, Czech Republic) at a temperature of $550^{\circ} \mathrm{C}$.

Determination of wet gluten was carried out according to standard ISO 21415 1:2006. ${ }^{37}$ The method requires preparation of dough from a sample of flour and a buffered solution of sodium chloride, isolation of the wet gluten by washing this dough with a buffered solution of sodium chloride (washing out by hand or mechanically), followed by removing excess washing solution and weighing the residue. ISO 21415 1:2006 specifies a manual washing out method for the determination of the wet gluten content of wheat flour (Triticum aestivum L. and Triticum durum Desf.). This method is directly applicable to flour. It is also applicable to semolina and wheat after grinding, if their particle size distribution meets the given specification. ${ }^{38,39}$

Metabolizable energy for poultry was calculated according to following regress equation $^{40}$ :

$\mathrm{ME} \mathrm{MJ} \cdot \mathrm{kg}^{-1}=34.31 \times \operatorname{Fat}\left(\mathrm{g} \cdot \mathrm{g}^{-1}\right)+15.51 \times \mathrm{CP}\left(\mathrm{g} \cdot \mathrm{g}^{-1}\right)+16.69 \times \operatorname{Starch}\left(\mathrm{g} \cdot \mathrm{g}^{-1}\right)+$ $13.01 \times \operatorname{Sugar}\left(\mathrm{g} \cdot \mathrm{g}^{-1}\right)$.

Protein digestibility was determined by an in vitro enzymatic hydrolysis method 
with the enzyme pepsin using a Daisy II Incubator (ANKOM Technology, Macedon, NY, USA) followed by the Kjeldahl method for CP analysis. ${ }^{34} \mathrm{CP}$ content and contents of three protein fractions (albumins and globulins, gliadins, and glutelins) were obtained by the method according to Osborn, measured by the standard method according to Kjeldahl and using the protein converting factor $6.25 .{ }^{41}$

Each nutritive value for both untreated and treated grains was determined several times. Values obtained by the analyses mentioned previously were compared with recommended table values in Zeman et al. ${ }^{42}$

\section{Seed Germination Tests}

The experiments for germination of the rapeseed Brassica napus were also carried out as described in part II.A. The influence of both atmospheric and low pressure plasmas was compared. The germination was determined and compared with germination of untreated seeds. The treatment time varied from 0 to $10 \mathrm{~min}$. The same duration time was set in both plasma configurations, the atmospheric pressure discharge of gliding arc type and the low pressure microwave generated plasma discharge. The other parameters of plasma devices were set in the same manner used for the tests of mycotoxin decontamination. The germination tests were performed on Petri dishes under the same laboratory conditions for 6 days. Five replicates and 150 seeds for each plasma treatment were tested. The number of germinated seeds was monitored.

\section{RESULTS AND DISCUSSION}

\section{A. Mycotoxin Decontamination}

The results of the tests for mycotoxin decontamination are depicted in Fig. 3. The treatment time up to $5 \mathrm{~min}$ was used only for low pressure microwave generated plasma treatment. Because of the higher temperature of the gliding arc discharge at atmospheric pressure, the seeds were treated for onlyv4 min to prevent their damage.

The decrease of relative mycotoxin content is evidently achieved with both types of plasma devices. For atmospheric plasma, the DON mycotoxin content decreased along whole treatment time to approximately $82 \%$ of initial value, but the reduction is not as rapid as for low pressure treatment. The mycotoxin T-2 content decreased more quickly to $40 \%$. However it can be distorted by the fact that the measureable amount of the mycotoxin T-2 was found only in two contaminated samples.

A slightly different situation occurs in the case of low pressure plasma treatment. The relative mycotoxin contents decreased very rapidly during the first 1-2 minutes of the treatment for both measured mycotoxins. The contents decreased to $28 \%$ and $38 \%$ of their initial values, respectively. On the other hand, ongoing treatment does not cause subsequent decrease, but by contrast the relative contents slowly increased. This result can probably be explained by additional production of mycotoxins by fungi that survived plasma treatment. At the end of $5 \mathrm{~min}$ of low pressure treatment, the rela- 


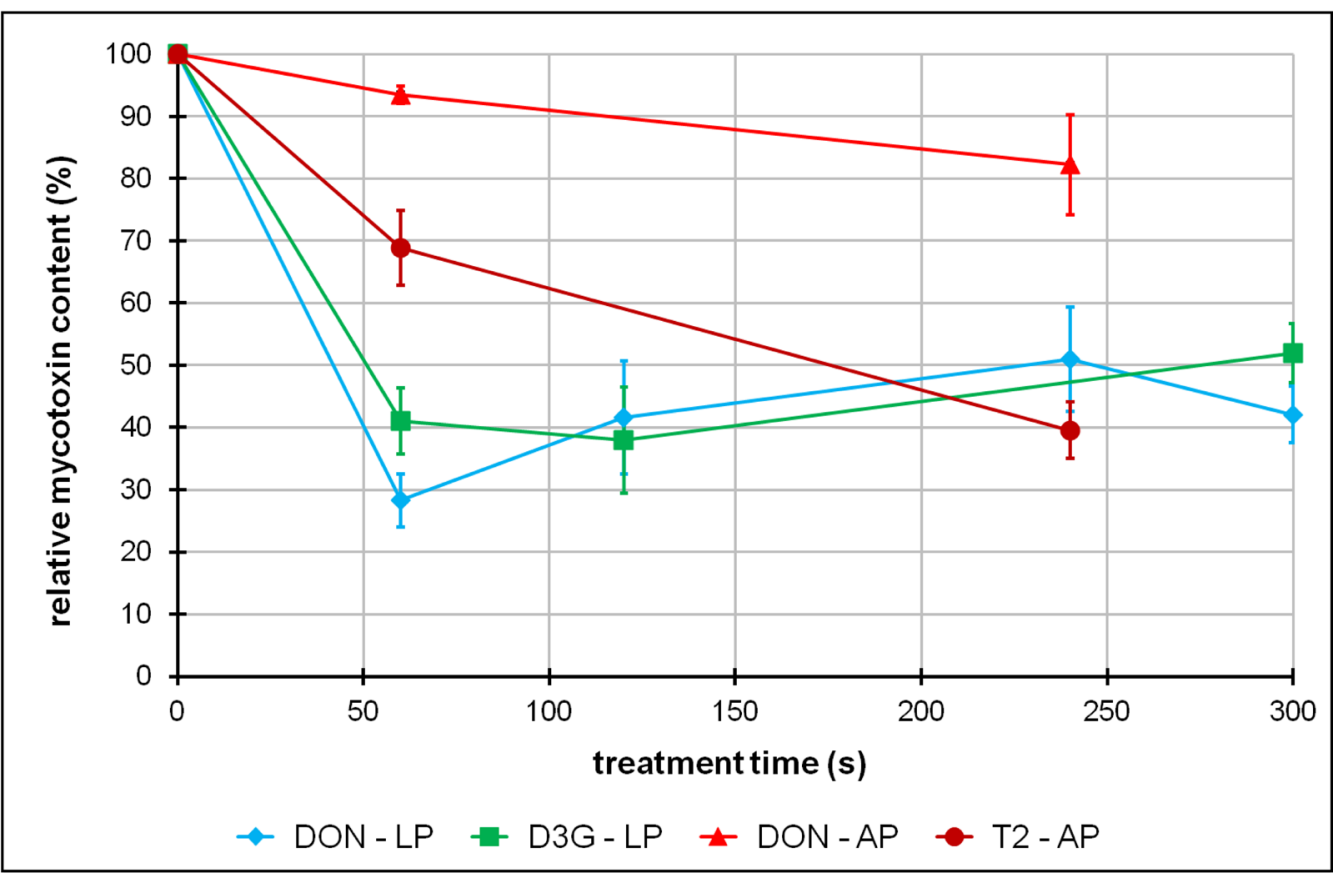

FIG. 3: Dependence of relative mycotoxin content on treatment time (DON, deoxynivalenol; D3G, deoxynivalenol-3- $\beta$-D-glucoside; T2, T-2 toxin; LP, low pressure plasma; AP, atmospheric pressure plasma)

tive mycotoxin contents were approximately $54 \%$ and $42 \%$, respectively, in comparison with their initial values.

As the experiments mentioned previously proved the possibility of grain decontamination from mycotoxins, the plasma treatment can be used as an ecologically friendly method for animal feed protection against fungi and their metabolic products. So for this purpose, we had to investigate the influence of plasma treatment on the basic seed nutritive values.

\section{B. Nutriment Analyses}

In the first stage, dry matter content in treated and untreated Triticosecale Wittm. seeds has been measured. Its dependence on plasma treatment time for two different air flows is shown in Fig. 4. Obviously the dry matter content increased with treatment time. The analogous trend was observed for every treated grain sample. It is a very important phenomenon, because higher dry matter content worsens fungal growth conditions, and so it is useful protection during grain storage. In addition, plasma treatment can represent an additional drying process before grain storage.

Relative content of other investigated nutriments in $100 \%$ of dry matter and its 


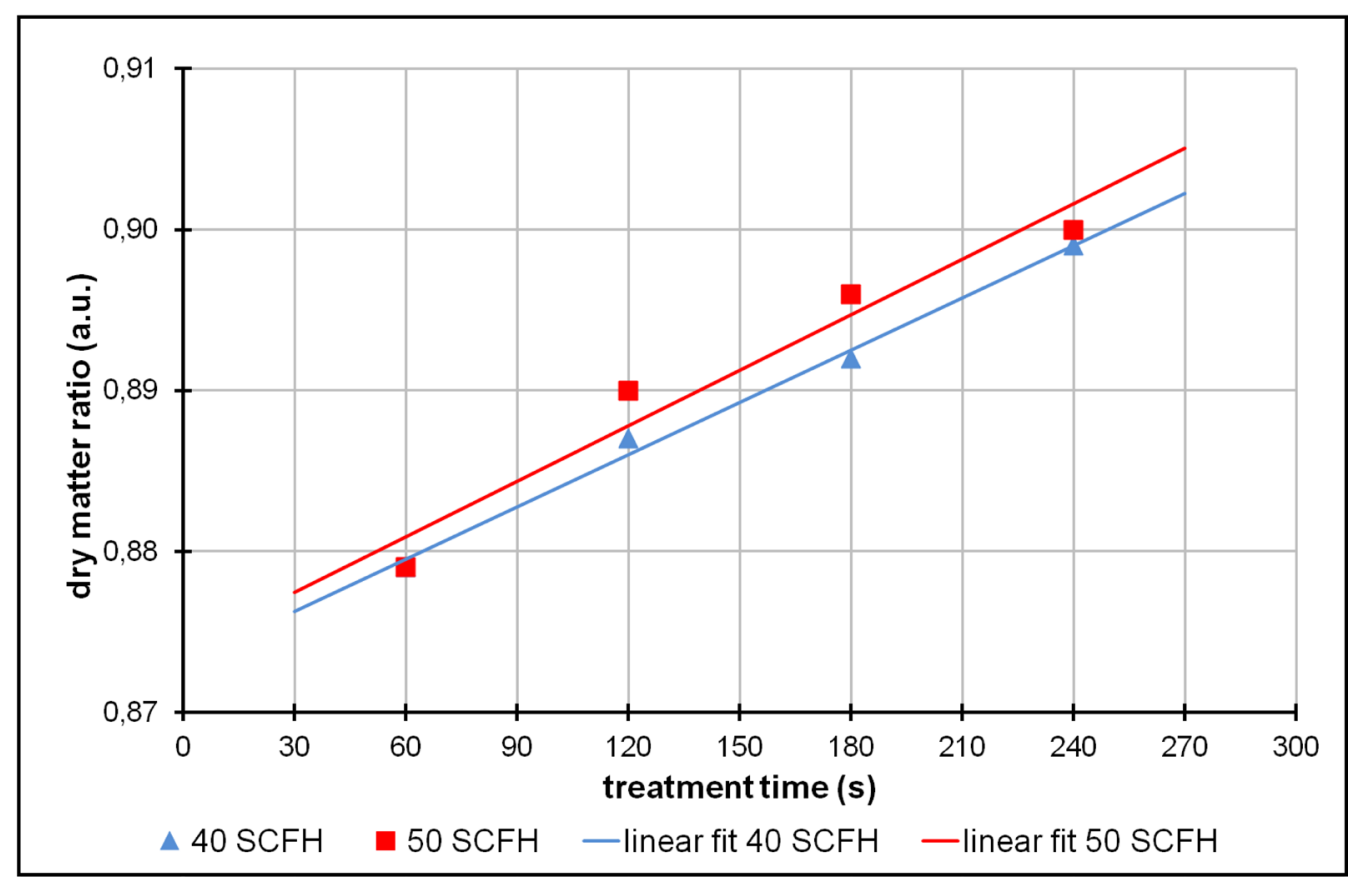

FIG. 4: Dependence of dry matter ratio on treatment time

dependence on treatment time is demonstrated in Fig. 5. Five measurements for every treated sample and every nutritional parameter were performed. It is evident that individual nutriments fluctuated a little. The changes were so small that the values fell within recommended table intervals in every measurement. ${ }^{42}$

The trend of increasing dry matter content and no significant changes in NFE, CF, fat, and ash amounts were again confirmed in tests with Triticum aestivum. In addition, these tests verified negligible changes of other nutriments, in particular starch, CP, protein digestibility, and individual nitrogen fractions. Albumins, globulins, gliadins, and glutelins were not notably affected by plasma treatment. Because of this, ME was also nearly unchanged. It was also verified that content of various types of amino acids is influenced only insignificantly. Wet gluten content was the only monitored nutritive parameter that was changed considerably by plasma treatment. It was shown that the relative content of wet gluten in treated grains dry matter decreased approximately $9 \%$ in the case of 1 min treatment compared to untreated samples. In the case of the longer 4 min treatment, the decrease was approximately two times higher than that for the 1 -min treatment. This phenomenon is very useful for the health of livestock and humans because a lower content of wet gluten is beneficial for the alimentary canal. 


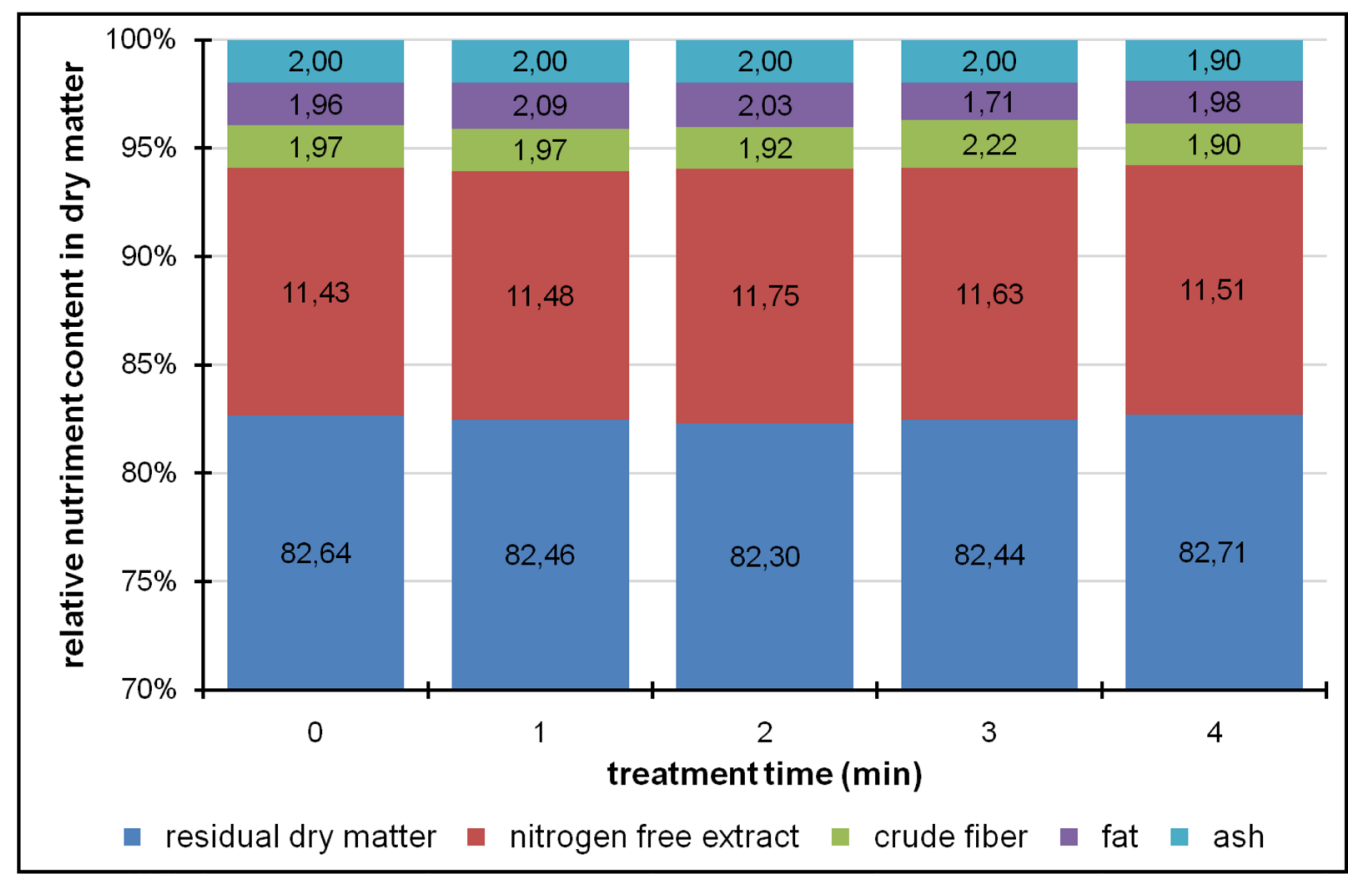

FIG. 5: Comparison of relative nutriment contents in dry matter from different treatment time

\section{Germination Tests}

Plasma treated seed germination tests were also carried out to determine whether plasma treatments can protect seeds that are stored before repeated sowing. The results of germination tests are shown in Fig. 6. Here there is a big difference between applications of atmospheric or low pressure plasma device. Rapeseed germination is stimulated by low pressure plasma, and the number of sprouted seeds is even higher than for untreated samples. It verified similar results already presented in some papers. ${ }^{16-19}$ However, the atmospheric pressure treatment resulted in a very rapid decrease in the germination of the seeds. The probable cause of the decrease is that the higher temperature of the atmospheric gliding arc plasma exceeded $100^{\circ} \mathrm{C}$ in the vicinity of the plasma jet, and so an undesirable thermal effect of the plasma can destroy the seeds.

\section{CONCLUSIONS}

From our experiments, tests, and analyses we can conceive following conclusions:

The plasma treatment can reduce mycotoxin content in the seeds in a very short treatment time, but it is necessary to perform additional experiments to optimize the process and to more fully understand the decontamination mechanism. 


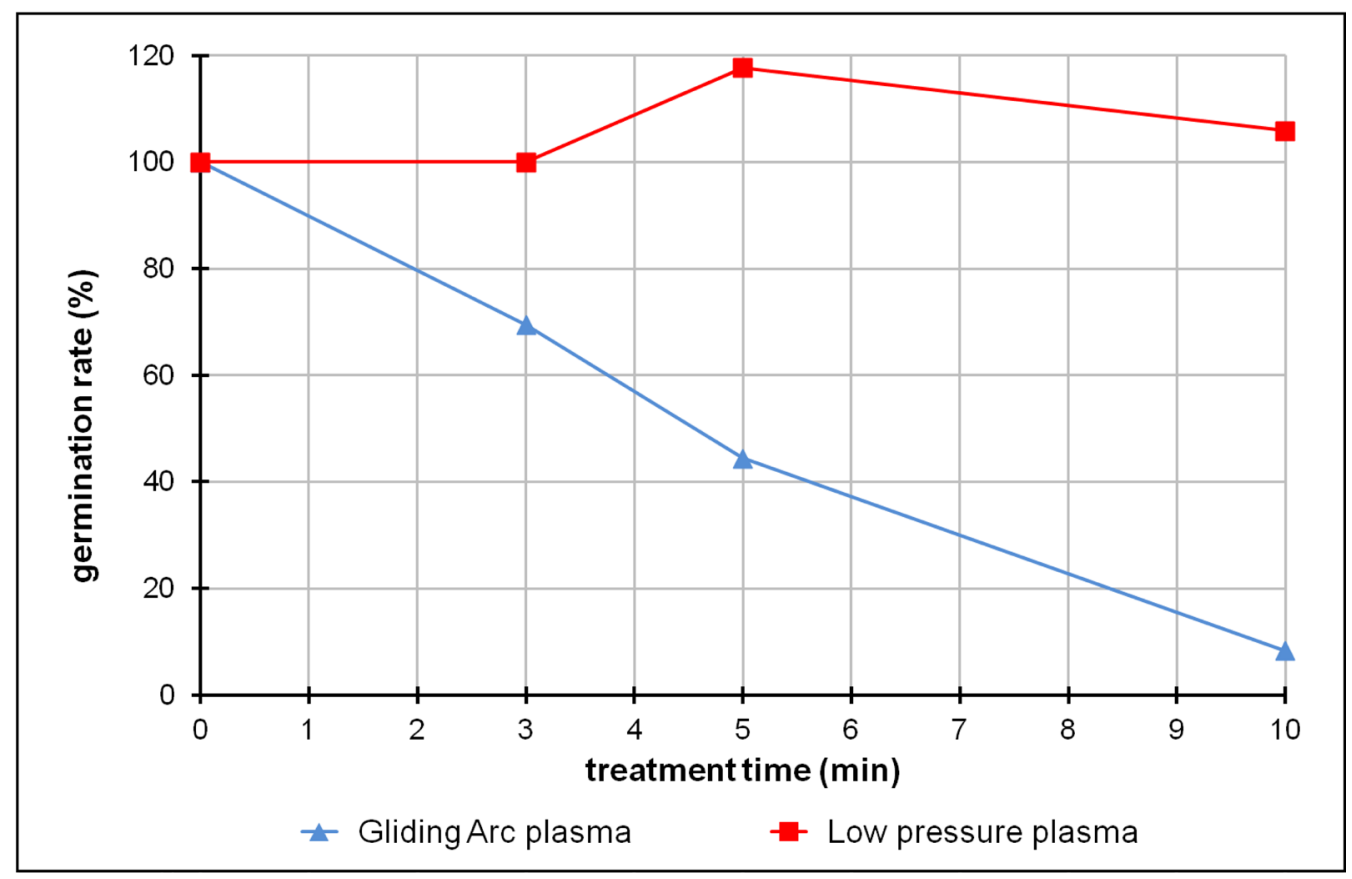

FIG. 6: Germination rate of treated rapeseeds compared to untreated seeds (germination of untreated seeds corresponds to the value $100 \%$ )

The plasma treatment can be used as an ecologically friendly method for animal feed protection against fungi and their metabolic products, because the nutritive indicators are not affected in terms of the food science and technology.

The plasma treatment has high added value consisting of an additional drying effect on the grains.

\section{ACKNOWLEDGMENT}

Financial support by the Grant Agency of the South Bohemia University GAJU $102 / 2013 / \mathrm{S}$ is highly appreciated.

\section{REFERENCES}

1. Laroussi M. Nonthermal decontamination of biological media by atmospheric-pressure plasmas: review, analysis, and prospects. IEEE Trans Plasma Sci. 2002;30(4):1409-15.

2. Gaunt LF, Beggs CB. Georghiou GE. Bactericidal action of the reactive species produced by gas-discharge nonthermal plasma at atmospheric pressure: a review. IEEE Trans Plasma Sci. 2006;34(4):1257-69.

3. Maeda Y, Igura N, Shimoda M, Hayakawa I. Bactericidal effect of atmospheric gas plasma on Escherichia coli K12. Int J Food Sci Tech. 2003;38(8):889-92. 
4. Selwyn GS, Herrmann HW, Park J, Henins I. Decontamination of chemical and biological warfare (CBW) agents using an atmospheric pressure plasma jet (APPJ). Phys Plasmas. 1999;6(5):2284.

5. Lee K, Peak KH, Ju WT, Lee Y. Sterilization of bacteria, yeast, and bacterial endospores by atmospheric-pressure cold plasma using helium and oxygen. J Microbiol. 2006;44(3):26975.

6. Morgan NN, Metawa A, Garamoon AA. Direct and indirect plasma yeast sterilization. Fizika A. 2010;19(2):83-92.

7. Vickery K, Deva AK, Zou J, Kumaradeva P, Bissett L, Cossart YE. Inactivation of duck hepatitis B virus by a hydrogen peroxide gas plasma sterilization system: laboratory and in use testing. J Hosp Infect. 1999;41(4):317-22.

8. Xiong Z, Lu X. P, Feng A, Pan Y, Ostrikov K. Highly effective fungal inactivation in $\mathrm{He}+\mathrm{O} 2$ atmospheric-pressure nonequilibrium plasmas. Phys Plasmas. 2010;17:123502.

9. Locoq E, Leclaire C, Clement F, Orial G, Panousis E, Ricard A. Parametric study of afterglows issued from dielectric barrier discharges in nitrogen and air and applied on Aureobasidium fungi. J Phys: Conf Ser. 2010;207(1):012008.

10. Avramidis G, Stuwe B, Wascher R, Bellmann M, Wieneke S, von Tiedemann A, Viöl W. Fungicidal effects of an atmospheric pressure gas discharge and degradation mechanisms. Surf Coat Technol. 2010;205(Supp 1):S405-S408.

11. Montie TC, Kelly-Wintenberg K, Raece Roth J. An overview of research using the one atmosphere uniform glow discharge plasma (OAUGDP) for sterilization of surfaces and materials. IEEE Trans Plasma Sci. 2000;28(1):41-50.

12. Vleugels M, Shama G, Deng XT, Greenacre E, Brocklehurst T, Kong MG. Atmospheric plasma inactivation of biofilm-formng bacteria for food safety control. IEEE Trans Plasma Sci. 2005;33(2):824-8.

13. Uhm HS, Hong YC, Shin DH. A microwave plasma torch and its applications. Plasma Sources Sci T. 2006;15(2):S26-S34.

14. Fridman G, Friedman G, Gutsol A, Shekhter AB, Vasilets VN, Fridman A. Applied plasma medicine. Plasma Process Polym. 2008;5(6):503-33.

15. Vasileva TM, Chukchin DGA. Comparative study of the structure of products of plasma modification of globular and fibrillar proteins. High Energ Chem. 2010;44(5):436-42

16. Volin JC, Denes FS, Young RA, Park SMT. Modification of seed germination performance through cold plasma chemistry technology. Crop Sci. 2000;40(6):1706-18.

17. Yin M, Mingjing H, Buzhou M, Tengcai M. Stimulating effects of seed treatment by magnetized plasma on tomato growth and yield. Plasma Sci Technol. 2005;7(6):3143-7.

18. Carvalho RAM, Carvalho AT, Silva MLP, Demarquette NR, Assis OBG. Use of thin films obtained by plasma polymerization for grain protection and germination enhancement. Quím Nova. 2005;28(6):1006-9.

19. Sera B, Spatenka P, Sery M, Vrchotova N, Hruskova I. Influence of plasma treatment on corn germination and early growth. IEEE Trans Plasma Sci. 2010;38(10):2963-8.

20. Perni S, Liu DW, Shama G, Kong M. Cold atmosphere plasma decontamination of the pericaps of fruit. J Food Protect. 2008;71:302-8.

21. Basaran P, Basaran-Akgul N, Oksuz L. Elimination of Aspergillus parasiticus from nut surface with low pressure cold plasma (LPCP) treatment. Food Microbiol. 2008;25(4):626-32.

22. Selcuk M, Oksuz L, Basaran P. Decontamination of grains and legumes infected with Aspergillus spp. and Penicillium spp. by cold plasma treatment. Bioresour Technol. 
2008;99(11):5104-9.

23. Lancova K, Hajslova J, Poustka J, Krplova A, Zachariasova M, Dostalek P, Sachambula L. Transfer of Fusarium mycotoxins and 'masked' deoxynivalenol (deoxynivalenol-3-glucoside) from field barley through malt to beer. Food Addit Contam Part A Chem Anal Control Expo Risk Assess. 2008;25(6):732-44.

24. Kostelanska M, Hajslova J, Zachariasova M, Malachova A, Klachova K, Poustka J, Fiala J, Scott PM, Berthiller F, Krska R. Occurrence of deoxynivalenol and its major conjugate deoxynivalenol-2-glucoside in beer and some brewing intermediates. J Agric Food Chem. 20;57(8):3187-94.

25. Malachova A, Vaculova K, Hrstkova P, Hajslova J, Ehrenbergerova J, Kostelanska M, Zachariasova M, Urbanova J, Cerkal R, Safrankova I, Markova J. Fusarium mycotoxins in spring barley and their transfer into malt. Kvasný Průmysl. 2010;56(3):131-7.

26. Bhat R, Rai RV, Karim AA. Mycotoxins in food and feed: present status and future concerns. Compr Rev Food Sci Food Saf. 2010;9:57-81.

27. Karlovksy P. Biological detoxification of the mycotoxin deoxynivalenol and its use in genetically engineered crops and feed additives. Appl Microbiol Biotechnol. 2011;91(3):491-504.

28. Schneiderová P. Bezpečnost krmiv a zdraví zvířat - mykotoxiny [pdf available on the Internet]. 2008 Mar 26 [cited 2015 Oct 30]. Available from: http://www.agronavigator.cz/UserFiles/File/Agronavigator/Schneiderova/Mykotoxiny\%20End.pdf.

29. Park JB, Takatori K, Sugita-Konishi Y, Kim IH, Lee MH, Han DW. Degradation of mycotoxins using microwave-inducted argon plasma at atmospheric pressure. Surf Coat Tech. 2007 Feb;201(9):5733-7.

30. Hladik J, Spatenka P, Aubrecht 1, Pichal J. New method of microwave plasma treatment of HDPE powders. Czech J Phys. 2006;56 Suppl B:S1333-8.

31. Kriz P, Haisan C, Spatenka P. Characterization of the gliding arc device for industry applications. In: Clotea LR, Gerigan C, Cernat M, editors. 2012 13th International Conference on Optimization of Electrical and Electronic Equipment (OPTIM), 2012 May 24-26, Brasov, Romania. Brasov: Transilvania University of Brasov; 2012. p. 1337-40.

32. Zheng MZ, Richard JL, Binder J. A review of rapid methods for the analysis of mycotoxins. Mycopathologia. 2006;161(5):261-73.

33. Czech standard ČSN 467092 (467092), Testing methods for feeding stuffs. (1998). Czech.

34. Kacerovsky O, Babicka L, Biro D, Heger J, Jedlicka Z, Lohnisky J, Mudrik Z, Roubal P, Svobodova M, Vencl B, Vratny P, Zelenka J. Zkoušení a posuzování krmiv (Testing and evaluation of feedstuffs). Praha: Státní zemědělské nakladatelství; 1990. Czech.

35. ISO 5983-1:2005 Animal feeding stuffs - Determination of nitrogen content and calculation of crude protein content including its corrigendum ISO 5983-1:2005/AC:2009-04.

36. ISO 6865:2000 Animal feeding stuffs - Determination of crude fibre content - Method with intermediate filtration.

37. ISO 21415-1:2006 Wheat and wheat flour - Gluten content - Part 1: Determination of wet gluten by a manual method.

38. Bordei D, Bahrim G, Paslaru V, Gasparotti C, Elisei A, Banu I, Ionescu L, Codina G. Controlul calitatii in industria panificatiei. Editura Academica. Galati. 2007. Romanian.

39. Miś A. Some methodological aspects of determining wet gluten quality by the glutomatic method (a laboratory note). Int Agrophys. 2000;14(2):263-7.

40. Zelenka J, Zeman L, Koci S, Kocova Z. Requirement of nutriments and tables of nutritive value of feeds for poultry. Brno: Czech Agriculture Academy Science. 1993. Czech. 
41. Dvoracek V, Moudry J, Curn V. Studies of protein fraction in grain of spelt wheat (Titicum spelta L.) and common wheat (Tritium aestivum L.). Scientia Agriculturae Bohemica. 2001;32(4):287-305.

42. Zeman L, Simecek K, Krasa A, Simek M, Lossmann J, Trinacty J, Rudolfova S, Vesely P, Hap I, Dolezal P, Kracmar S, Tvrznik P, Michele P, Zemanova D, Siske V. Animal feed catalogue. VÚVZ Pohořelice. 1995. Czech. 